\title{
New Onset Type-1 Diabetes Mellitus in a Toddler with Sars-Cov- 2 Infection Presenting In Diabetic Ketoacidosis: A Case Report
}

Ekezie JC ${ }^{1}$, and Haddad D ${ }^{2}$.

${ }^{1}$ Department of Pediatrics, BronxCare Health System, New York, USA.

${ }^{2}$ Division Of Pediatric Intensive Care, Department of Pediatrics, Maria Fareri Children's Hospital, Westchester Medical Center, New York, USA.

*Corresponding Author: Ekezie JC, Department of Pediatrics, BronxCare Health System, 1650 Selwyn Avenue, Bronx NY, USA.

Received date: July 17, 2021; Accepted date: August 13, 2021; Published date: August $23,2021$.

Citation: Ekezie JC, and Haddad D, New Onset Type-1 Diabetes Mellitus in a Toddler with Sars-Cov-2 Infection Presenting In Diabetic Ketoacidosis: A Case Report, J. New Medical Innovations and Research, 2(5): DOI: 10.31579/2767-7370/022.

Copyright: (C) 2021 Ekezie JC. This is an open-access article distributed under the terms of The Creative Commons Attribution License, which permits unrestricted use, distribution, and reproduction in any medium, provided the original author and source are credited.

\begin{abstract}
Introduction: Severe acute respiratory syndrome coronavirus 2 (SARS-CoV-2), though mostly sparing the lungs in children, has been found to affect other organs including the endocrine pancreas. Type 1 diabetes mellitus (T1DM) may occur through direct negative effects of the virus on beta cell function leading to diminished insulin production. Diabetic ketoacidosis (DKA) is a known and life-threatening complication of T1DM.

Case presentation: This is a case of a 3-year-old previously healthy male who presented with 4 days history of fever, with malaise and hyperpnea for one day. Review of systems was notable for increased thirst and urination, nausea, vomiting, fatigue, and visible weight loss for 4 days. Initial investigations done showed elevated blood glucose, ketonuria, increased anion gap metabolic acidosis, and positive SARS-CoV-2 polymerase chain reaction (PCR). He was immediately commenced on intravenous fluids and insulin with progressive improvement and was discharged on hospital day 6.

Conclusion: Coronavirus disease-2019 (COVID-19) has impacted children most profoundly with the new postinfectious multi-inflammatory syndrome, however it is important to remember that primary coronavirus infection is still a threat to pediatric patients, for example, its cytotoxic effects on the pancreatic beta cells that may lead to T1DM. We therefore recommend that caregivers, parents, and medical professionals should have a high index of suspicion when children present with symptoms consistent with a diagnosis of T1DM during the COVID-19 pandemic so that diagnosis can be made promptly and DKA prevented.
\end{abstract}

Keywords: type 1 diabetes mellitus; diabetic ketoacidosis; SARS-CoV-2; COVID-19

\section{Introduction}

Multiple reports on the current coronavirus disease 2019 (COVID-19) caused by severe acute respiratory syndrome coronavirus 2 (SARS-CoV2) have described asymptomatic infection and mild self-resolving infection in children without progression to lower pulmonary disease requiring hospitalization as seen in adults [1]. However, SARS-CoV-2 infection, though mostly sparing the lungs in children, is now seen to be affecting other organs including the endocrine system [2,3]. The most common reported endocrine comorbidity associated with COVID-19 is diabetes mellitus which occurs when SARS-CoV-2 enters the islet cells via angiotensin-converting enzyme 2 (ACE2) receptors and damages the beta cells causing decreased or absent insulin production which leads to hyperglycemia [4,5]. Type 1 diabetes mellitus (T1DM; previously called insulin-dependent diabetes) is predominantly seen in children and adolescents [6]. Recent studies have shown a global trend of increasing prevalence of T1DM which may be multifactorial including the rising prevalence of obesity and increased awareness [6], and more recently, the COVID-19 pandemic [7]. In a multi-centered study in United Kingdom, 30 children aged 23 months to 16.8 years presented with new-onset T1DM during the peak of the pandemic, 5 of whom had evidence of acute or recent SARS-CoV-2 infection; an 80\% increase in cases of T1DM was estimated to be associated with the pandemic [7]. Diabetic ketoacidosis (DKA) is the most common complication of T1DM and can be potentially fatal [8]. We present a case of new-onset T1DM presenting as DKA in a 3-year-old child with SARS-CoV-2 infection.

\section{Case Presentation}

The patient is a 3-year-old previously healthy male who presented with 4 days history of fever and generalized body weakness, and "deep breathing" for 1 day. On review of systems, the mother reported increased thirst and urination, vomiting, fatigue, and visible weight loss for 4 days. 
There is no family history of type 1 diabetes mellitus or autoimmune disease, however maternal grandfather had a history of type 2 diabetes. Patient was afebrile on presentation, and physical examination was significant for Kussmaul breathing and an ill-appearing toddler. Results of investigations done showed - blood glucose 582, pH 6.9, anion gap 23, lactate $2.7 \mathrm{mmol} / \mathrm{L}$, urine ketones $2+(80 \mathrm{mg} / \mathrm{dl})$, urine glucose $3+(>=$ $500 \mathrm{mg} / \mathrm{dl}$ ), which made the diagnosis of DKA. SARS-CoV-2 reverse transcriptase polymerase chain reaction (RT-PCR) is done routinely on patients who require inpatient hospitalization and was positive. In the pediatric intensive care unit, patient was given titratable intravenous fluids and a continuous infusion of insulin, while blood glucose, venous blood gas, basic metabolic panel, and urine ketones were closely monitored (Table 1). Subsequent laboratory findings include elevated HbA1c (10.0\%), low insulin $(<15 \mathrm{mIU} / \mathrm{L})$, and low C-peptide $(<0.1$ $\mathrm{ng} / \mathrm{ml})$ which confirmed an underlying diagnosis of T1DM. Antibodies to insulin and glutamic acid decarboxylase 65 (GAD 65) were within normal range $(<0.4 \mathrm{U} / \mathrm{mL}$ and $<5 \mathrm{IU} / \mathrm{mL}$ respectively). Screening for celiac disease and thyroid disorders were also within normal limits (Table 1).

\begin{tabular}{|c|c|}
\hline \multirow[t]{2}{*}{ VBG } & First: pH 6.95, pCO2 19, pO2 35, HCO3 4.2, BE -26.6 \\
\hline & Final: $\mathrm{pH} 7.37, \mathrm{pCO} 232, \mathrm{pO} 2$ 75, $\mathrm{HCO} 3$ 18.5, $\mathrm{BE}-5.8$ \\
\hline \multirow[t]{2}{*}{ BMP } & First: $\mathrm{Na} 134, \mathrm{~K} 4.8, \mathrm{HCO} 3<6, \mathrm{Cl} 111, \mathrm{BUN} 16, \mathrm{Cr} 1.24$, Gluc 582 \\
\hline & Final: $\mathrm{Na}$ 140, K 3.5, HCO3 13, Cl 120, BUN 11, Cr 0.65, Gluc 138 \\
\hline \multirow[t]{2}{*}{ Urinalysis } & $\begin{array}{l}\text { First: pH 6, SG 1.028, glucose } 3+(>=500 \mathrm{mg} / \mathrm{dl}) \text {, ketones } 2+(80 \mathrm{mg} / \mathrm{dl}) \text {, protein } 2+(100 \mathrm{mg} / \mathrm{dl}) \text {, } \\
\text { nitrite negative, LE negative }\end{array}$ \\
\hline & $\begin{array}{l}\text { Final: pH 9, SG 1.011, glucose } 3+(>=500 \mathrm{mg} / \mathrm{dl}) \text {, ketones negative, protein negative, nitrite } \\
\text { negative, LE negative }\end{array}$ \\
\hline Respiratory multiplex panel & $\begin{array}{l}\text { SARS-CoV-2 RT-PCR: Positive } \\
\text { Influenza A: Negative } \\
\text { Influenza B: Negative } \\
\text { RSV: Negative }\end{array}$ \\
\hline $\mathrm{CBC}$ & WBC 26.5, Hb 12.9, Hct 41.2, N 70.3, L 18.1, M 8.3, B 0.3, E 0, Plt 406 \\
\hline CRP & $<0.1 \mathrm{mg} / \mathrm{dl}$ \\
\hline Serum osmolality & $322 \mathrm{mOsm} / \mathrm{kg}$ \\
\hline Hemoglobin A1c & $10.0 \%$ \\
\hline C-peptide & $<0.1 \mathrm{ng} / \mathrm{ml}$ \\
\hline Insulin autoantibody & $<0.4 \mathrm{U} / \mathrm{ml}$ \\
\hline Insulin & $<15.7 \mathrm{mIU} / \mathrm{L}$ \\
\hline $\begin{array}{l}\text { Gliadin deaminated } \operatorname{IgA} \\
\text { antibody }\end{array}$ & $<10.0 \mathrm{U}$ \\
\hline $\begin{array}{l}\text { Gliadin deaminated } \operatorname{IgG} \\
\text { antibody }\end{array}$ & $<10.0 \mathrm{U}$ \\
\hline TTG IgG antibody & $9 \mathrm{U} / \mathrm{ml}$ \\
\hline GAD65 antibody & $<5 \mathrm{IU} / \mathrm{mL}$ \\
\hline BNP & $24 \mathrm{pg} / \mathrm{ml}$ \\
\hline Troponin I & $<0.02 \mathrm{ng} / \mathrm{ml}$ \\
\hline $\begin{array}{ll}\text { Thyroid } & \text { peroxidase } \\
\text { antibody }\end{array}$ & $<1$ \\
\hline Thyroglobulin antibody & $<1.8$ \\
\hline $\begin{array}{l}\text { Thyroglobulin tumor } \\
\text { marker }\end{array}$ & $30 \mathrm{ng} / \mathrm{ml}$ \\
\hline
\end{tabular}

B: Basophils, BE: Base excess, BMP: Basic metabolic panel, BNP: Brain natriuretic peptide, BUN: Blood urea nitrogen, CBC: Complete blood count, Cl: Chloride, Cr Creatinine, CRP: C-reactive protein, E: Eosinophils, GAD65: Glutamic acid decarboxylase 65, Gluc: Glucose, Hb: Hemoglobin, HCO3: bicarbonate, Hct: Hematocrit, L: Lymphocytes, LE: Leukocyte esterase, M: Monocytes, N: Neutrophils, Na: Sodium, pCO2: Partial pressure of carbon dioxide, pO2: Partial pressure of oxygen, SG: Specific gravity, RSV: Respiratory syncytial virus, TTG: Tissue transglutaminase, VBG: Venous blood gas, WBC: white blood cell.

Glucose rates progressively declined at a rate less than $100 \mathrm{mg} / \mathrm{dl}$ per hour. Acidosis resolved and anion gap closed on day 1 of admission. On day 2 of admission, he was transitioned to subcutaneous insulin and started on diabetic diet regimen and received subsequent care and education by the pediatric endocrinologist on the general pediatrics floor. He was discharged on hospital day 6 . He had no further complications and had no respiratory symptoms throughout his hospital stay.

\section{Discussion}

The association between COVID-19 and new-onset type 1 diabetes mellitus (T1DM) is becoming increasingly frequent. This case highlights the possibility of SARS-CoV-2 acting as an infectious precipitant for
T1DM. Although the presence of multiple autoantibodies greatly increases the probability for T1DM with about $96 \%$ of affected individuals being positive for at least one of the autoantibodies [9], this patient did not have autoantibodies, which may suggest a different mechanism of pancreatic beta cell insufficiency. Children have been mostly spared the life-threatening sequelae of coronavirus infection in the lungs, and the current understanding is that pediatric nasal and lung epithelial cells have less ACE2 receptors that permit viral entry; also, these receptors have lower affinity for SARS-CoV-2 and a different distribution in the body, making SARS-CoV-2 entry into the cells more difficult [10]. However, ACE2 receptors are known to be present in pancreatic beta cells causing direct viral cytotoxicity and decreased 
insulin production leading to diabetes [4,5]. There are concerns that the reported increase in presentations of children with T1DM already in a state of DKA during the COVID-19 pandemic may be attributed to delayed presentation to primary care physicians and hospitals to reduce risk of exposure to the virus [11], however, similar to the UK report, [7] the index patient had a relatively short duration of symptoms and the acuity of presentation may be as a result of the SARS-CoV-2 infection. It is important for individual patient care as well as for the pediatric community to be aware that children are still at risk from primary coronavirus infection even if they do not get frequent pneumonias.

\section{Conclusion}

In conclusion, it is possible that we are seeing a rapid onset of severe acute disease due to COVID-19 in children which may be attributable to pancreatic viral destruction based on the science that we have in adults. We therefore recommend that caregivers, parents, and medical professionals should have a high index of suspicion so that diagnosis can be early and DKA potentially prevented. We hope that future studies including the ongoing CoviDIAB Project [3] will address questions on predisposing factors, treatment, and prognosis of COVID-19-related diabetes.

\section{Acknowledgement}

The authors wish to acknowledge the staff of the pediatric intensive care unit of MFCH for their diligent and meticulous care of patients including the index case.

\section{Declaration}

\section{Funding: None}

Ethics approval: Ethical approval was waived by the Institutional Review Board as the report involved less than five patients.

Consent for publication: Not applicable as de-identified data was used.

Conflict of interest: The authors have no conflict of interest to declare.

Authors' contributions: The first author drafted the article while the second author critically reviewed it.

\section{References}

1. Rubens JH, Akindele NP, Tschudy MM, Sick-Samuels AC (2021). Acute covid-19 and multisystem inflammatory syndrome in children. BMJ. (372):n385.

2. Lim S, Bae JH, Kwon HS, Nauck MA (2021). COVID-19 and diabetes mellitus: from pathophysiology to clinical management. Nat Rev Endocrinol.;17:11-30.

3. Rubino F, Amiel SA, Zimmet P, Alberti G, Bornstein S, Eckel $\mathrm{RH}$, et al (2020). New-Onset Diabetes in Covid-19. N Engl J Med;383(8):789-790.

4. Apicella M, Campopiano MC, Mantuano M, Mazoni L, Coppelli A, Del Prato S (2020). COVID-19 in people with diabetes: understanding the reasons for worse outcomes. Diabetes \& Endocrinology;8(9):p782-p792.

5. Boddu SK, Aurangabadkar G, Kuchay MS (2020). New onset diabetes, type 1 diabetes and COVID-19. Diabetes Metab Syndr;14(6):2211-2217.

6. Mobasseri M, Shirmohammadi M, Amiri T, Vahed N, Hosseini Fard H, Ghojazadeh M (2020). Prevalence and incidence of type 1 diabetes in the world: a systematic review and metaanalysis. Health Promot Perspect;10(2):98-115.

7. Unsworth R, Wallace S, Oliver NS, Yeung S, Kshirsagar A, Naidu H, et al (2020). New-Onset Type 1 Diabetes in Children During COVID-19: Multicenter Regional Findings in the U.K. Diabetes Care;43(11):e170-e171.

8. Dhatariya KK, Glaser NS, Codner E, Umpierrez GE (2020). Diabetic ketoacidosis. Nat Rev Dis Primers;6(1):40.

9. Regnell SE, Lernmark $\AA$ (2017). Early prediction of autoimmune (type 1) diabetes. Diabetologia;60(8):1370-1381.

10. Zimmermann P, Curtis N (2020). Why is COVID-19 less severe in children? A review of the proposed mechanisms underlying the age-related difference in severity of SARS-CoV-2 infections. Arch Dis Child;0:1-11.

11. International Society of Pediatric and Adolescent Diabetes (ISPAD) (2020). Summary of recommendations regarding COVID-19 in children with diabetes: Keep Calm and Mind your Diabetes Care and Public Health Advice. Pediatr Diabetes;21(3):413-414.

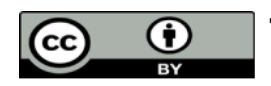

This work is licensed under Creative Commons Attribution 4.0 License

To Submit Your Article Click Here: Submit Manuscript

DOI: $10.31579 / 2767-7370 / 022$

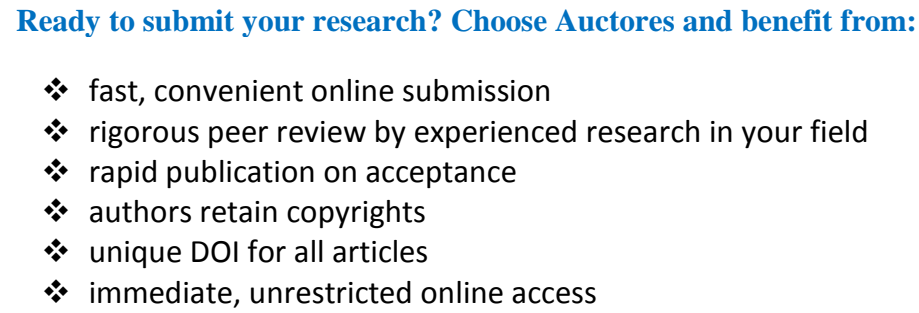

Ready to submit your research? Choose Auctores and benefit from:

* fast, convenient online submission

* rigorous peer review by experienced research in your field

* rapid publication on acceptance

* authors retain copyrights

* unique DOI for all articles

* immediate, unrestricted online access

At Auctores, research is always in progress.

Learn more www.auctoresonline.org/journals/new-medical-innovationsand-research 